\title{
Wspomnienia o doktorze Marcinie Winiarskim
}

Doktor Marcin Winiarski należał do grupy nauczycieli akademickich, której wartości i znaczenia w edukacji studentów formalnie nie doceniono w żadnej ustawie kształtującej warunki i zadania szkolnictwa wyższego.

Obowiązująca ustawa z dnia 20 lipca 2018 roku Prawo o szkolnictwie wyższym i nauce (Dz.U. z 2018 r. poz. 1668) oraz wcześniejsze regulacje w ocenie nauczycieli akademickich posługują się sformalizowanymi kryteriami oceny ich osiągnięć, których podstawową „miarą” jest dorobek publikacyjny — liczba, objętość, miejsce i język (najlepiej obcy) publikacji. Kryteria te wyznaczają także progi uczelnianych awansów. A przecież „miary” te potwierdzają co do zasady predyspozycje do pracy badawczej i nie przekładają się na kwalifikacje dydaktyczne w procesie kształcenia stanowiącego istotę oraz cel tworzenia szkół wyższych (w odróżnieniu od placówek badawczych) i nie wartościują jego kompetencji dydaktycznych.

Tymczasem współcześnie, gdy nowoczesne technologie informatyczne umożliwiają powszechny dostęp do wiedzy, jej źródeł i form przekazu, rynek pracy oczekuje od absolwentów szkół wyższych innych kompetencji zawodowych, wykraczających poza zasób wiedzy uzyskanej w toku studiów na danym kierunku i specjalności. Jednocześnie studenci oczekują od swoich nauczycieli innych treści i form przekazu.

Te oczekiwania rodzą potrzebę reorientacji procesu kształcenia studentów, to jest odchodzenia od dominującego „nauczania”, opartego na przekazywaniu wiedzy podręcznikowej, teoretycznej, kształtującego tak zwane kompetencje twarde, w kierunku „uczenia” polegającego na kształtowaniu tak zwanych kompetencji miękkich, społecznych, potrzeby kształcenia ustawicznego, pozyskiwania nowych umiejętności zawodowych, adaptacyjności do wielokrotnej zmiany miejsca i charakteru pracy. Takie umiejętności są niezbędne w warunkach dynamicznie 
zmieniającego się otoczenia społeczno-gospodarczego, niestabilności zatrudnienia, zdarzeń losowych kształtujących sytuacje osobiste absolwentów.

Kształcenie studentów ery cyfrowej wymaga czegoś więcej niż tylko realizacji dotychczasowych programów studiów, „nauczania” na ćwiczeniach i wykładach oraz kontrolowania efektów tego procesu przez zaliczenia i egzaminy, które mają potwierdzić uzyskanie twardych kompetencji. „Uczenie” wykracza poza ustalony administracyjnie program studiów wyrażony liczbą przedmiotów oraz godzin zajęć i wymaga dodatkowej aktywności nauczyciela, niemieszczącej się w ustawowym pensum dydaktycznym. Tym bardziej na uznanie i szacunek oraz dobra pamięć zasługują nauczyciele, którzy nie tylko nauczali, lecz także uczyli przez wiele lat studentów Wydziału Prawa, Administracji i Ekonomii. Rozwijali ich kompetencje społeczne i zawodowe przez różne formy działalności, kształtowali pozytywne postawy, przygotowali do samodzielnego budowania ścieżki zawodowej kariery.

Takim nauczycielem akademickim niewątpliwie był dr Marcin Winiarski, bo to o Nim są powyższe słowa. Nie sposób wyliczyć wszystkich przedsięwzięć, których był inicjatorem i organizatorem, realizowanych przez i z udziałem studentów, będących przez wiele lat trwałym elementem studiów ekonomicznych na tym Wydziale.

Na szczególną pamięć zasługuje rola dr. Marcina Winiarskiego w działalności Naukowego Koła Ekonomistów (NKE). Był inicjatorem jego powołania, a następnie opiekunem, kreatorem i inspiratorem wielu niekonwencjonalnych przedsięwzięć, nieprzerwanie od 2001 do 2016 roku. Koło, wielokrotnie wyróżniane i nagradzane przez władze Wydziału i uczelni, zorganizowało dwadzieścia trzy konferencje, w tym czternaście międzynarodowych.

Trudno przecenić Jego udział w trafnym doborze inspirujących tematów, pozyskiwaniu sponsorów, pracochłonnej organizacji tych konferencji, zwłaszcza kilkudniowych (wyjazdowych) z udziałem studentów zagranicznych. NKE dzięki inspiracji dr. Marcina Winiarskiego było też współorganizatorem corocznego „Dnia Ekonomii”. Dzięki Jego osobistemu zaangażowaniu w roli referentów i moderatorów występowali między innymi przedstawiciele środowisk biznesowych (prezesi międzynarodowych korporacji), artystycznych (dyrektor Narodowego Forum Muzyki, ówczesny dyrektor Teatru Polskiego) czy innych nieczęsto goszczących w murach Wydziału.

Aktywność dr. Marcina Winiarskiego wykraczała poza uczelnię, czego przykładem jest Jego współpraca z Wrocławskim Parkiem Technologicznym SA, mająca różne formy organizacyjne. Dzięki niej Zarząd i Rada Nadzorcza spółki wielokrotnie udzielały wsparcia NKE w organizacji studenckich konferencji naukowych, udostępniając w swojej siedzibie sale na obrady oraz zapewniając catering ich uczestnikom. 
Wrocławski Park Technologiczny SA współfinansował także wydanie kolejnych tomów „Studenckich Prac Prawniczych, Administratywistycznych i Ekonomicznych", których dr Marcin Winiarski był redaktorem naczelnym od drugiego do dziewiętnastego numeru. Uzyskane wsparcie finansowe zapewniło temu unikalnemu czasopismu ciągłość wydawniczą.

Gdy w 2011 roku WPT SA założył fundację Pro Mathematica (KRS 0000394473), której celem poza wspieraniem nowatorskich oraz wartościowych edukacyjnie i wychowawczo metod uczenia w zakresie przedmiotów ścisłych była także organizacja konferencji, szkoleń i innych imprez naukowych, dr Marcin Winiarski został powołany przez fundatora (Zarząd WPT SA) na członka Rady Fundacji I kadencji.

Abiit non obiit.

Urszula Kalina-Prasznic ORCID: 0000-0002-3407-4919 Wyższa Szkoła Prawa we Wrocławiu 